\title{
STRATEGIE KOMUNIKACYJNE JAKO SPOSÓB NA SKUTECZNE KOMUNIKOWANIE SIE MIMO NIEDOSTATKÓW JĘZYKOWYCH
}

Słowa kluczowe: strategie komunikacyjne, język polski jako obcy, język mówiony

Streszczenie. Autorka omówiła pojęcie strategii komunikacyjnych oraz dwa najpopularniejsze podejścia badawcze: interakcyjne i socjolingwistyczne. Przedstawiła działania strategiczne uczących się języka polskiego jako obcego, które pojawiały się podczas zajęć odbywających się w Studium Języka Polskiego dla Cudzoziemców Uniwersytetu Łódzkiego zarówno w trakcie obserwacji lekcji, jak i podczas prowadzonych przez autorkę zajęć. Wśród omówionych strategii znalazły się: strategie osiągnięć (parafraza, porównywanie, uproszczenie, stosowanie synonimów, tworzenie neologizmów oraz przełączanie kodu językowego), prośba o pomoc, użycie środków niewerbalnych oraz strategie uniku. Autorka omówiła również przykłady negocjowania znaczeń oraz wykorzystywanie nowoczesnych technologii, jako narzędzia pomocnego przy stosowaniu strategii komunikacyjnych.

\section{DEFINIOWANIE STRATEGII KOMUNIKACYJNYCH}

Cudzoziemcy podejmujący próby porozumiewania się w języku polskim zarówno podczas zajęć, jak i w sytuacjach pozalekcyjnych, miewają problemy ze skutecznym przekazywaniem komunikatów. By wykonać zamierzone zadanie komunikacyjne, muszą wykazać się umiejętnościami radzenia sobie z niedostatkami językowymi. Działania te nazywane są strategiami komunikacyjnymi. Ich stosowanie wynika z kompetencji strategicznej uczących się, która została wyróżniona w modelu kompetencji komunikacyjnej Canale'a i Swain (1980). Strategie komunikacyjne definiowane są przez Europejski system opisu ksztatcenia językowego ${ }^{1}$ (2003, s. 61) jako:

*wojtczak.edyta@gmail.com, Uniwersytet Lódzki, Wydział Filologiczny, Instytut Filologii Polskiej i Logopedii, Zakład Lingwistyki Stosowanej i Kulturowej, ul. Pomorska 171/173, 90-236 Łódź.

${ }^{1}$ W skrócie ESOKJ. 
środki wykorzystywane przez użytkownika języka w celu mobilizacji i kontroli własnych zasobów językowych oraz uaktywnienia własnych umiejętności i sposobów działania, by w najpełniejszy lub najbardziej ekonomiczny sposób, zgodnie z założonym celem i danym kontekstem komunikacyjnym, skutecznie wykonać dane zadanie.

Według ESOKJ strategie komunikacyjne, które stosują użytkownicy języka, są wynikiem sprawnego wykorzystywania posiadanych już umiejętności językowych. Mówiący musi wykazać się swoistą kreatywnością, by osiągnąć cel komunikacyjny. ESOKJ podkreśla, że działania te uczący się stosuje: „W celu osiągnięcia maksymalnej skuteczności” (ESOKJ 2003, s. 62).

Stanisław Piotrowski (2016, s. 27) zwraca uwagę na to, że:

z perspektywy uczącego się komunikacja w języku, który on dopiero przyswaja, odbywa się w sytuacji chronicznego niedoboru środków. Deficyty w różnych obszarach szeroko pojętej kompetencji komunikacyjnej (a więc zarówno na poziomie systemu języka, jak i reguł konwersacyjnych) mogą znacząco utrudniać, a czasami uniemożliwiać komunikację i/albo wykonanie określonego zadania. To właśnie w tych newralgicznych - problematycznych z punktu widzenia przebiegu interakcji - miejscach pojawiają się specyficzne zachowania komunikacyjne, zwane strategiami komunikacyjnymi.

Strategie komunikacyjne są tu więc postrzegane jako wszelkie zachowania komunikacyjne mające na celu umożliwienie wykonania danego zadania mimo deficytów w obszarze kompetencji komunikacyjnej.

Stosując różnego rodzaju działania strategiczne, uczący się nie zawsze muszą być tego świadomi. Wspomnieli o tym Fearch i Kasper (1983, s. 36), definiując strategie komunikacyjne jako:

potencjalnie świadome plany rozwiązania tego, co dana jednostka uznaje za trudność w osiągnięciu zamierzonego celu komunikacyjnego w trakcie porozumiewania się w obcym dla siebie języku (za: Żurek 2018, s. 68)².

\section{PODEJŚCIE PSYCHOLINGWISTYCZNE I INTERAKCYJNE}

Liczne opracowania anglojęzyczne związane z zagadnieniem strategii komunikacyjnych przyczyniły się do powstania różnych podejść badawczych. Należy tu wspomnieć o dwóch najbardziej popularnych, czyli o podejściach psycholingwistycznym i interakcyjnym. Pierwsze z nich, nazywane również kognitywnym, traktuje strategie komunikacyjne jako procesy psychiczne zachodzące $\mathrm{w}$ umysłach uczących się. Wszelkie działania strategiczne obejmują dwa etapy: planowanie wypowiedzi oraz wykonane zadania komunikacyjnego. Powyższy sposób badania strategii komunikacyjnych przyjęli Faerch i Kasper (1983). Przedstawiciele tego nurtu postulują prowadzenie badań, obejmujących procesy poznawcze

\footnotetext{
${ }^{2}$ Tłum. Żurek 2018, s. 68.
} 
stanowiące podstawę strategicznego użycia języka. Za błędne metodologicznie uważają poddawanie analizie wyłącznie wypowiedzi, czyli zwerbalizowanych efektów procesów psychologicznych (por. Dornyei, Scott 1997). Prowadzący badania wyrażają wątpliwości związane z nauczaniem strategii komunikacyjnych, ponieważ według nich użytkownicy, wraz ze wzrostem znajomości języka docelowego, nabywają również umiejętności dostosowywania się do różnych sytuacji komunikacyjnych. Wspominała o tym Bialystok zwracając uwagę, że: „to, czego należy uczyć, to nie strategie, a język" (Bialystok 1990, s. 147), oraz Kellerman sugerując: „nauczajmy języka, a strategie same o siebie zadbają” (Kellerman 1991, s. 158).

Drugim podejściem badawczym obecnym w badaniach nad strategiami komunikacyjnymi jest podejście interakcyjne, nazywane też socjolingwistycznym, w którym podkreśla się dynamiczny charakter interakcji zachodzącej między rozmówcami. Wszelkie opisy strategii komunikacyjnych tworzy się tu na podstawie tego, co zostało już „wyprodukowane”. Badacze nie zajmują się opisem procesów psychicznych mogących mieć wpływ na dane działania mówiącego. Yule i Tarone (1997) podkreślają, że analizy, w których język docelowy jest punktem odniesienia, mogą być niezwykle pomocne przy ocenie sukcesu uczących się w jego przyswajaniu oraz samej skuteczności strategii komunikacyjnych. Badacze wskazują również, że ocena przydatności działań strategicznych w dużej mierze jest możliwa dzięki analizie „wynegocjowanego wkładu” (negotiated input). Zwolennicy podejścia interakcyjnego postulują nauczanie strategii komunikacyjnych.

Różnice między podejściem psycholingwistycznym i interakcyjnym przedstawiają się następująco:

Tabela 1. Podsumowanie różnic między podejściem interakcyjnym i psycholingwistycznym

\begin{tabular}{|l|l|}
\hline \multicolumn{1}{|c|}{ PODEJŚCIE INTERAKCYJNE } & PODEJŚCIE PSYCHOLINGWISTYCZNE \\
\hline ekspansja kategorii & redukowanie kategorii \\
\hline taksonomiczny opis zaobserwowanej produkcji & opis procesów kognitywnych \\
\hline porównywanie z językiem docelowym & porównywanie z językiem ojczystym \\
\hline $\begin{array}{l}\text { elicytacja (elicitation prompts) z użyciem } \\
\text { realnych obiektów (real-world objects) }\end{array}$ & $\begin{array}{l}\text { elicytacja (elicitation prompts) z użyciem } \\
\text { abstrakcyjnych kształtów (abstract shapes) }\end{array}$ \\
\hline obecność rozmówcy & brak rozmówcy \\
\hline uczący się o różnych narodowościach & uczący się tej samej narodowości \\
\hline zalecane nauczanie strategii komunikacyjnych & $\begin{array}{l}\text { brak zaleceń dotyczących nauczania strategii } \\
\text { komunikacyjnych }\end{array}$ \\
\hline
\end{tabular}

Źródło: Yule, Tarone (1997, s. 28 [tłum. E.W.]) 
Jak można zauważyć, w podejściu interakcyjnym przewiduje się tworzenie nowych kategorii strategii komunikacyjnych. Jeśli analizowaniu podlega to, co zostało „wyprodukowane" przez mówiących, to może pojawić się potrzeba stworzenia kolejnej kategorii, która obejmowałaby dotychczas nigdzie niesklasyfikowany typ działania. Takiej możliwości nie ma w przypadku podejścia psycholingwistycznego, w którym redukuje się liczbę kategorii. Wszelkie działania mówiących opisywane są w ramach dwóch głównych typów, którymi są strategie uniku (zmiana celu komunikacyjnego) lub strategie osiągnięć (realizacja celu za pomocą dostępnych środków). Ważne jest tu nie tylko wykonanie zadania komunikacyjnego, ale również sam proces planowania.

W powyższym zestawieniu badacze zawarli informację o sposobach elicytacji materiału językowego. W podejściu interakcyjnym wykorzystywano $\mathrm{w}$ tym celu konkretne obiekty (real-world objects) ${ }^{3}$. Mówiący często opisywali funkcję danego przedmiotu lub jego części czy właściwe mu cechy takie, jak: kolor, materiał wykonania itp. Natomiast w podejściu psycholingwistycznym wykorzystywano abstrakcyjne kształty (abstract shapes) $)^{4}$. W efekcie uczący się posługiwali się analogiami czy omówieniami. Wskazano również na to, że często stosowane strategie były takie same zarówno dla rodzimych użytkowników danego języka, jak i dla uczących się go cudzoziemców. Jedynie sposób ich wykonania był inny. Badacze zwrócili uwagę, że rodzaj elicytacji materiału językowego wpływał na częstość stosowania konkretnych strategii komunikacyjnych. W związku z tym za niezbędne uznali połączenie obu sposobów elicytacji, by wydobyć jak najbardziej różnorodne działania strategiczne uczących się. We współczesnych badaniach nad strategiami komunikacyjnymi nie wykorzystuje się już wspomnianych dwóch typów elicytacji w zależności podejścia badawczego.

W podejściu interakcyjnym, jak sama nazwa wskazuje, niezwykle ważna jest sama interakcja między mówiącymi. W konsekwencji zakłada się obecność rozmówców, między którymi ona zachodzi. Punktem odniesienia jest język docelowy, ponieważ może zaistnieć sytuacja, w której uczestnicy komunikacji są różnej narodowości, a więc ich języki pierwsze też są różne. Należy więc za punkt odniesienia obrać to, co ich łączy, czyli w tym przypadku język, którego się uczą. Natomiast w podejściu psycholingwistycznym nie uwzględnia się rozmówcy przy wyborze danego działania strategicznego, co badacze określili jako brak rozmówcy.

Dodatkowo w zestawieniu został wyróżniony podział ze względu na narodowości uczących się. Podczas gdy w podejściu interakcyjnym prowadzono badania wśród uczących się różnych narodowości, to w podejściu psycholingwi-

${ }^{3}$ Badacze w prowadzonych badaniach podali przykład elicytacji autorstwa Kellermana i in. (1990) polegającej na tym, że uczący się zostali poproszeni o opisanie jednego z elementów zaparzacza do kawy.

${ }^{4}$ Badacze podali przykład, w którym uczący się odnosili się do kształtu podkowy. 
stycznym badani posługiwali się tym samym językiem pierwszym lub ich języki ojczyste były bardzo podobne do języka docelowego. Na dobór strategii komunikacyjnych przez uczących się miały wpływ aspekty geograficzne, historyczne czy socjokulturowe.

Wspomniane już negocjowanie znaczeń odgrywa ważną rolę w podejściu interakcyjnym. Umożliwia ono również ocenę przydatności danych strategii. Jeśli stosowanie niektórych $\mathrm{z}$ nich pomaga $\mathrm{w}$ osiągnięciu celu komunikacyjnego, to według zwolenników tego podejścia należy ich nauczać, by pomóc uczącym się usprawnić komunikację mimo braków językowych.

Podczas prowadzenia zajęć z cudzoziemcami uczącymi się języka polskiego, obserwowania zajęć prowadzonych przez innych lektorów, przyglądania się komunikacji studentów cudzoziemskich podczas przerw czy bycia świadkiem sytuacji (pozalekcyjnych), kiedy to obcokrajowcy próbowali skomunikować się z Polakami, niejednokrotnie mogłam przekonać się, że strategie komunikacyjne są nieodłącznym elementem procesu komunikacji. W związku z tym wydaje mi się, że należy zastanowić się nad sposobami, które wykorzystywane są przez cudzoziemców w celu efektywnej komunikacji.

Dokonując analizy różnego rodzaju działań uczących się należy pamiętać, że ich celem musi być potencjalnie świadome przezwyciężenie napotkanego podczas komunikacji problemu. W związku z powyższym, zbieranie materiału językowego oraz jego późniejsza analiza wymaga od badacza obecności przy wypowiedziach. Pozwala to zweryfikować, czy dane działanie można uznać za strategię komunikacyjną. Podczas zbierania materiału bywa to trudne, ponieważ uczący się mogą stosować strategie w sposób niezauważalny dla rozmówców (zwłaszcza na wyższych poziomach zaawansowania językowego).

\section{PRZYKLADOWE DZIALANIA STRATEGICZNE UCZĄCYCH SIĘ JĘZYKA POLSKIEGO JAKO OBCEGO}

Poniżej przedstawiam przykłady strategii komunikacyjnych stosowanych przez obcokrajowców podczas lektoratu języka polskiego. Wśród nich są takie, które pojawiły się zarówno w czasie zajęć prowadzonych przeze mnie, jak i przez innych lektorów ${ }^{5}$, kiedy to byłam wyłącznie bierną obserwatorką zachodzących działań komunikacyjnych.

W swoich badaniach nie skupiam się na analizowaniu procesów psychicznych zachodzących w umysłach uczących się. Koncentruję się na tym, co zostało już „wyprodukowane”, by w efekcie poddać dane działanie strategiczne wery-

${ }^{5}$ Obserwacje zajęć prowadziłam w Studium Języka Polskiego dla Cudzoziemców Uniwersytetu Łódzkiego. 
fikacji, co do jego przydatności w procesie komunikowania się i osiągania celu komunikacyjnego podczas interakcji zachodzącej między rozmówcami (bardzo często różnych narodowości).

Klasyfikując działania strategiczne, stosuję poziomy biegłości językowej według Europejskiego systemu opisu ksztatcenia językowego (2003), który wyróżnia:

- poziom podstawowy: A1 (Breakthrough) i A2 (Waystage);

- poziom samodzielności: B1 (Threshold) i B2 (Vantage);

- poziom biegłości: C1 (Effective Operational Proficiency) i C2 (Mastery).

Przedstawione strategie zostały zastosowane przez uczących się różnych narodowości. W grupach wielonarodowościowych znajdowali się studenci z całego świata i były to zajęcia prowadzone na poziomie podstawowym (A1 i A2) oraz progowym (B1), a w grupach polonijnych studenci z Europy Wschodniej, których poziom biegłości językowej można było określić jako poziom samodzielności (B1 i B2).

\title{
3.1. STRATEGIE OSIĄGNIĘĆ
}

Europejski system opisu ksztatcenia językowego definiuje strategie osiągnięć jako:

\begin{abstract}
sięganie do wykraczającego ponad własny poziom możliwości i znajdowanie sposobów na radzenie sobie z zadaniami z górnej pótki [...]. Użytkownik języka wykazuje pozytywne podejście do swoich możliwości, stosując takie strategie osiągnięć, jak: stosowanie podobnych środków wyrazu i uogólnień przy zastosowaniu prostszego języka; parafrazowanie tego, co chce się wyrazić, a nawet kalkowanie wyrażeń z własnego (pierwszego) języka (kompensacja); częste odwoływanie się do dobrze znanych i „sprawdzonych” wyrażeń - „wysyp pewności” - tworzących punkty oparcia, na których można polegać, nawet, gdy cała sytuacja lub temat są całkiem nowe (budowanie na uprzedniej wiedzy); próby stosowania sformułowań, które się ledwo pamięta, lecz sądzi, iż mogą zadziałać (wypróbowanie). (ESOKJ 2003, s. 66)
\end{abstract}

\subsubsection{Parafraza}

Wśród strategii osiągnięć można wyróżnić takie działania jak parafraza, czyli wyrażanie tej samej treści innymi środkami językowymi. Umożliwia ona mówiącym kontynuowanie swojej wypowiedzi mimo trudności spowodowanych brakami językowymi. Strategia ta była dość często stosowana w przypadku braków leksykalnych 
Jest osoba, kiedy dwie inne rozmawiają, ale nie rozmawiają i ona jest jak most dla nich.

(Węgry, poziom A2) ${ }^{6}$

Mówiący posłużył się tutaj porównaniem do funkcji, którą pełni most, czyli łączenie ze sobą dwóch brzegów w celu umożliwienia przedostania się na drugą stronę, na przykład rzeki. Tutaj funkcję mostu pełni osoba, która pomaga porozumiewać się osobom, skłóconym lub niemającym ze sobą kontaktu (kiedy dwie osoby rozmawiaja, ale nie rozmawiaja), czyli pośrednik.

W kolejnym przykładzie mówiący następująco określił nienarodzone jeszcze dziecko:

Pacjentem lekarza nawet jest dziecko, które znajduje się... yyy... no w matce!

(Ukraina, poziom B2)

Mówiący dokonał uproszczenia: dziecko, które znajduje się w matce, podczas gdy właściwsze byłoby: dziecko, które znajduje się w brzuchu matki, lub po prostu nienarodzone dziecko.

\subsubsection{Porównanie}

Cudzoziemcy próbowali porównywać brakujące słowo do innego, które znali, np.:

Rano zawsze jem orzechy... yyy ... nie wiem... orzech jak mózg.

(Francja, poziom A1)

W powyższym przykładzie uczący się posłużył się porównaniem. Użyte słowo mózg przywołało skojarzenie z kształtem, który odpowiadał szukanemu orzechowi włoskiemu.

\subsubsection{Uproszczenie}

Uczący się dokonywali również swego rodzaju parafrazy. Stosowali słowa, które pozwalały im ująć to, co chcieli powiedzieć w sposób mniej skomplikowany, np.:

Komórki przy Alzhaimerze... yyy... no robią się leniwe.

(Ukraina, poziom B2)

W powyższym przykładzie uczący się spowolnienie pracy komórek (neuronów), ich degenerację oraz obumieranie, opisał jako komórki robia się leniwe, co oczywiście pozwala zrozumieć intencję nadawcy, ale słowo leniwy nie jest

\footnotetext{
${ }^{6}$ Przykład przytoczyłam również w swoim artykule Wojtczak (2017).
} 
adekwatne zarówno do medycznej odmiany języka polskiego ${ }^{7}$, jak i do opisania danego zjawiska spowolnienia pracy neuronów.

Uczący się dokonywali również innych rodzajów uproszczeń, np.:

Ja uczę się języka polskiego wczoraj! Dużo, bardzo dużo!

$(\text { Iran, poziom A1) })^{8}$

Jest godzina... уyу... siedemna... уyу... siedemnaście. Nie wiem, jak dobrze mówić.

(Niemcy, poziom A1)

W pierwszym przykładzie mówiący dokonał uproszczenia morfologicznego, ponieważ wyraził przeszłość za pomocą czasu teraźniejszego (ja uczę się) i okolicznika czasu (wczoraj). Natomiast w drugim przykładzie zastosowano uproszczenie leksykalno-semantyczne. Uczący się wiedział, że w przypadku podawania godziny w języku polskim należy użyć liczebnika porządkowego (w tym przypadku siedemnasta), mimo że po napotkaniu trudności zrezygnował z jego użycia, upraszczając swoją wypowiedź, zastosował liczebnik główny (siedemnaście).

\subsubsection{Stosowanie synonimów}

W przypadku napotkania trudności uczący się stosowali również synonimy, np.:

Warto jeść produkty, które zaw... zaw... yyy..., które mają w sobie dużo witaminy C.

(Białoruś, poziom B2)

W powyższym przykładzie mówiący pamiętał wyłącznie początek słowa $z a$ wierać, próbował je sobie przypomnieć. Po nieudanych próbach nie poddał się, ale użył prostszego synonimu mieć w składzie (tu mieć w sobie).

\subsubsection{Tworzenie neologizmów}

Mówiący uciekali się też do tworzenia nowych słów. Wykazywali się przy tym kreatywnością słowotwórczą, np.:

Okulary. Na pewno nie przeciwsłoneczne. No myślę, że przeciwśniegowe... nie... nartowe!

(Ukraina, poziom B2)

Mówiący zaznaczył, że nie chodzi mu o okulary przeciwstoneczne, ale tym samym poprzez analogię okulary przeciw stońcu, zaproponował okulary przeciwśniegowe (przeciw śniegowi). Proponując nazwę: okulary nartowe, odniósł się

\footnotetext{
${ }^{7}$ Omawiany przykład jest fragmentem wypowiedzi studenta dopiero przygotowującego się na studia medyczne w Polsce, więc odmiana medyczna języka polskiego nie była mu zupełnie obca.

${ }^{8}$ Przykład przytoczyłam również w swoim artykule Wojtczak (2017).
} 
do innego przedmiotu z danego kręgu tematycznego (narciarstwa), by utworzyć przymiotnik od słowa narty. Żadna z zaproponowanych przez uczącego się nazwa nie była prawidłowa. Jednak zrozumienie tego, co miał na myśli mówiący, było możliwe.

\subsubsection{Przełączanie kodu językowego}

Inną grupą działań, którą stosowali cudzoziemcy w przypadku braku odpowiednich środków językowych, było przełączanie kodu językowego (code switching). W sytuacji niewystarczających środków językowych, uczący się stosowali pojedyncze słowa ze swoich języków pierwszych lub (częściej) z języka angielskiego, np.:

Jestem bardzo... bardzo tired dzisiaj.

(Indie, poziom A1)

To teraz jestem... уyy... jak po polsku? Nie wiem., yyy... jestem confused.

(Włochy, poziom A1)

Kolejnym zjawiskiem jest foreignizing. Termin ten stosowany jest w literaturze anglojęzycznej na określenie adaptacji słowa z języka pierwszego (lub pośredniego) pod względem fonologicznym lub morfologicznym, do zasad języka docelowego (Dornyei 1995; Poulisse 1990). Na gruncie polskim zjawisko to określane bywa, jako polonizacja wyrazu i polega na aktywizacji opanowanych języków (por. Sękowska 2010, s. 50; Żurek 2018, s. 162), np.:

Tak! To jest dobry... yyy... dobra solucja!

(Węgry, poziom A1)

Ja regularnie attenduję klasa.

(Grecja, poziom A1)

W obu przykładach uczący się z powodu braków leksykalnych próbowali przystosować angielskie słowa do polskich wzorców językowych. W pierwszym przykładzie uczący się dokonał adaptacji rzeczownika solution (rozwiązanie), natomiast druga wypowiedź stanowi przykład przystosowania czasownika (częsty w przypadku czasowników z sufiksem -ować). Czasownik attendować (brać udział, uczestniczyć) został odmieniony według polskiego wzorca koniugacyjnego attenduję. Dodatkowo uczący się odtworzył angielski schemat składniowy to attend class (brać udziat $w$ zajęciach), nie stosując przyimka $w$, niezbędnego w języku polskim dla konstrukcji tego typu. 


\subsection{PROŚBA O POMOC}

W przypadku napotkanych trudności językowych uczący się, obok stosowania różnego rodzaju strategii osiągnięć, prosili również o pomoc. Oprócz typowych pytań: Co to znaczy? Co znaczy [podaje stowo]? cudzoziemcy szukali aprobaty u lektora podczas mówienia, zarówno w zakresie leksyki, jak i poprawności gramatycznej, np.:

Student: I to działa tak uspokajajo..., uspokajają...? [pytające spojrzenie]

Lektorka: Uspokajająco.

Student: Tak, dziękuję. Uspokajająco.

(Białoruś, poziom B2)

Student: Białko zawiera się w mięs, nie... w mięsa? Mięs? [zastanawia się, uśmiech w stronę lektorki]

Lektorka: W mięsie.

Student: No dobrze, zawiera się w mięsie.

(Ukraina, poziom B2)

Źródłem pomocy często okazywała się sama grupa studentów uczestnicząca w zajęciach. Prośba o pomoc wyrażana była spojrzeniem, pstryknięciem palcami lub prośbą o pomoc w języku polskim, kiedy kierowano ją do wszystkich uczących się, lub w języku pierwszym czy języku pośrednim, gdy z prośbą o pomoc zwracano się do konkretnej grupy studentów (osób pochodzących z tego samego kraju, czy osób znających język angielski).

\subsection{UŻYCIE ŚRODKÓW NIEWERBALNYCH}

Wśród strategii komunikacyjnych stosowanych przez uczących się można wyróżnić również komunikację niewerbalną, a wśród nich komunikację kinezyjną, która opiera się na gestach, mimice i ruchu ciała. Jak wskazują Seretny i Lipińska (2005), ten typ komunikacji stosowany jest, między innymi przez osoby, które z powodu braku znajomości wspólnego kodu, nie mogą przekazywać sobie informacji. Są to zwłaszcza studenci początkujący. Poniżej przedstawiam przykładowe wypowiedzi uczących się języka polskiego z wykorzystaniem środków niewerbalnych.

W przypadku krwotoku trzeba położyć lód na [wskazuje czoło]. Aaaa! Zapomniałam! I trzeba tak głowę [odchyla głowę], ale nie za bardzo i długo.

(Ghana, poziom A2)

Lektorka: Jak wpływa kawa na nasze ciało?

Studentka: Dostajemy ładny wygląd na nasze ciało [pokazuje zarys szczupłej sylwetki]

(Zambia, poziom A2) 
Czy ja mogę? [student podszedł do włącznika światła i go dotknął]

(Węgry, poziom A1)

W przypadku braków leksykalnych uczący się, by przekazać komunikat, posługiwali się własnym ciałem oraz różnymi przedmiotami znajdującymi się w sali. Do komunikacji niewerbalnej można zaliczyć też pozostałe zachowania pozajęzykowe, takie jak wykorzystanie pozalingwistycznych środków akustycznych (np. naśladowanie dźwięków) czy wykorzystanie paratekstowych środków wyrazu (np. rysunki), o których wspomina ESOKJ.

\section{STRATEGIE UNIKU}

Obok strategii osiągnięć ESOKJ wymienia także strategie uniku, czyli różnego rodzaju działania polegające na dostosowaniu wypowiedzi do posiadanych przez mówiącego umiejętności, co często wiąże się z ograniczeniem przez niego stosowanych środków językowych (por. ESOKJ, s. 66). Ten typ strategii zakłada realizację celu komunikacyjnego, choć w mniejszej skali. Wśród zachowań mownych cudzoziemców uczących się języka polskiego można wyróżnić zachowanie polegające na unikaniu lub zaniechaniu przekazu, jednak ta grupa nie jest przedmiotem badań, które przedstawiam w niniejszym artykule, gdyż nie stanowi ona skutecznej realizacji celu komunikacyjnego.

\section{NEGOCJOWANIE ZNACZEŃ}

Podczas zajęć uczący się podejmowali próby negocjowania, z lektorem lub kolegami z grupy, znaczenia omawianych treści. Najczęściej występowało ono podczas wprowadzania nowego materiału, gdyż to właśnie wtedy informacje w największym stopniu podlegały analizie i interpretacji przez uczących się, którzy, chcąc zrozumieć wyraz, zwrot, konkretną formę gramatyczną czy intencje mówiącego, wchodzili w interakcje z lektorem lub pozostałymi uczestnikami zajęć (por. Kubacka 2014). Zjawisko to obejmuje różne typy strategii, co ilustrują poniższe przykłady.

Lektorka: Dlaczego tak niewyraźnie napisałeś tekst?

Student 1: Bo ten ołówek jest yyy... [patrzy na ołówek i pokazuje rękami, że jest duży/gruby] nie jest [pokazuje rękami, że jest cienki].

Student 2: Bo jest tlusty!

Lektorka: Nie, ołówek nie może być tłusty.

Student 2: Dobrze zbudowany? [zwrócił się z pytaniem do lektorki] 
Student 1: Nie! Tak niedobrze. On nie jest [wklada ołówek w zaciśniętą pięść i udaje, że temperuje ołówek]

Lektorka: Teraz rozumiem. Jest tępy. Nie jest zatemperowany.

(Student 1: Zimbabwe, Student 2: Nigeria, poziom A2)

Uczący się użył w komunikacji środków niewerbalnych: patrząc na ołówek pokazał, że jest duży/gruby, a następnie, że mały/cienki. Drugi student częściowo odczytał jego intencje, wiedział, że chodzi o coś większych rozmiarów. Chciał zastosować synonim, jednak użył niewłaściwego do danego kontekstu przymiotnika tlusty. Pierwszy student poddał tę wypowiedź korekcie, mówiąc: Nie, ołówek nie może być tlusty. Kolega z grupy nie poddał się i dalej szukał słowa oddającego właściwe znaczenie. Ponownie spróbował opisać ołówek przez podanie synonimu, zwracając się pytająco do lektorki: Dobrze zbudowany? Jednak pierwszy student nie czekał na odpowiedź, wiedząc, że określenie użyte przez jego kolegę nie było poprawne - Nie! Tak niedobrze. Ponownie użył środków komunikacji niewerbalnej, pokazując za pomocą zaciśniętej pięści temperowanie ołówka. Na koniec lektorka przysłuchująca się dyskusji studentów, podała właściwe słowa (tępy, niezatemperowany).

Student: Jak nazywa się osoba, która wyrabia odzież?

Lektorka: Nie rozumiem. Pytasz o...

Student: No jak Dolce Gabbana!

Lektorka: Projektant?

Studenci: Nie!

Student: No taki główny designer.

Studentka 1: Nie designer, bo on taki dla architektury.

Lektorka: Aniu, architekt.

Studentka 1: Aaa, architekt.

Studentka 2: To projektant, nie?

Student: Nie projektant no taki yyy... [mówi coś po ukraińsku]

Studentka 2: Po polsku, to jest lekcja polskiego Sasha!

Student: No dobrze, no ja nie wiem.... yyy... no po naszemu to modelier [patrzy pytająco na koleżanki z grupy]

Studentka 1: Tak, już wiemy. Projektant!

Student: Osoba, która wyrabia odzież to projektant?

Lektorka: Osoba, która projektuje to projektant.

Studentka 1: Tak Sasha, to jest projektant mody. Teraz dobrze.

(Ukraina, poziom B1)

Student zapytał lektorkę o nazwę dla osoby zajmującej się wyrabianiem odzieży (prośba o pomoc). Po niezrozumieniu przez nią pytania i próbie jego doprecyzowania, student przerwał i użył porównania jak Dolce Gabbana. Lektorka podała znaczenia słowa, które prawdopodobnie student miał na myśli - projektant. Jednak uczący się zaprzeczyli, a student kontynuował, podając parafrazę taki 
główny designer. Do rozmowy włączyła się studentka, która zanegowała to, co powiedział kolega: Nie designer, bo on taki dla architektury. Lektorka poprawiła studentkę, która podała błędną definicję. Następnie próbę znalezienia właściwego słowa podjęła druga studentka, która zgodziła się z tym, co powiedziała lektorka. Przyznała, że szukanym słowem jest projektant (użycie synonimu). Student zaprzeczył, że chciał użyć tego słowa i zwrócił się do koleżanek w języku ukraińskim. Próba przełączenia kodu napotkała się z oporem jednej ze studentek, która chciała rozmawiać po polsku. Zastanawiając się przez chwilę, student zakończył podaniem słowa po ukraińsku: modelier (przełączenie kodu językowego). Studentka potwierdziła, że słowo zaproponowane przez lektorkę było prawidłowe. Student podał definicję: Osoba, która wyrabia odzież to projektant. Lektorka dokonała korekty, zmieniając czasownik wyrabiać na projektować. Na koniec zniecierpliwiona studentka kolejny raz potwierdziła, że słowo, o które na samym początku pytał jej kolega, to właśnie projektant.

Przytoczone dialogi są przykładami pokazującymi, jak może przebiegać negocjowanie znaczeń na poziomach podstawowym i średniozaawansowanym. Środkami, których cudzoziemcy używali do przekazania komunikatów były: porównania, negacje, parafrazy, przełączanie kodu oraz różne środki komunikacji niewerbalnej. Bardzo często negocjowanie znaczeń na poziomie podstawowym ma formę niekomplikowanych i niejednokrotnie krótkich dialogów.

Można zauważyć, że na negocjowanie składa się wiele różnych działań. Wynika z tego wniosek, że im większa jest ich znajomość, tym większa kreatywność uczących się podczas negocjowania znaczenia. Natomiast uświadomienie sobie stopnia skuteczności danych strategii może wpłynąć na zwiększenie efektywności podczas komunikacji. Uczący się, w przypadku wystąpienia określonych trudności w akcie przekazania znaczenia, może korzystać z określonego inwentarza strategii komunikacyjnych. Dlatego uważam, że nauczanie strategii komunikacyjnych może okazać się w tym przypadku przydatne.

\section{STOSOWANIE NOWOCZESNYCH TECHNOLOGII}

Obecnie, nowoczesne technologie są ogólnodostępne. Można zauważyć, że uczący się często korzystają z nich podczas zajęć z języka polskiego jako obcego. Stanowią one pomocne narzędzie dla uczących się. Wśród zaobserwowanych przeze mnie zachowań jest, między innymi korzystanie ze słownika on-line. Smartphony gwarantują ciągły dostęp do Internetu, więc nie stanowi to problemu. Studenci tłumaczyli jedno słowo lub też (co jest częste w przypadku osób na poziomie podstawowym) - całe frazy. Następnie sami je czytali, pokazywali lektorowi thumaczenie widoczne na ekranie telefonu lub wykorzystywali opcję umoż- 
liwiającą przeczytanie przez słownik danego słowa (kiedy sami nie wiedzieli, jak to zrobić). Po tych czynnościach kontynuowali swoje wypowiedzi. Równie często korzystali z wyszukiwarki internetowej w celu odnalezienia zdjęcia ilustrującego słowo, którego nie znali (co jest przykładem wykorzystywania elementów strategii niewerbalnych). Uczący się języka polskiego mieli też zapisane w telefonie trudne słowa, zwroty, których często używali, a z których zapamiętaniem mieli problem, by w czasie komunikacji szybko wyszukać je z samodzielne stworzonej listy słów/zwrotów. Dokładnie wiedzieli, które słowo mieli na myśli, więc używając telefonu, usprawniali przebieg rozmowy.

Stosowanie urządzeń wykorzystujących nowoczesne technologie (bardzo często smartphone'ów, ale też tabletów czy laptopów) często zastępowało tradycyjne słowniki, fiszki czy notesy.

Przedstawione powyżej wypowiedzi pokazują sposoby radzenia sobie przez cudzoziemców w obliczu trudności językowych zaistniałych podczas komunikacji. Można je przedstawić graficznie w następujący sposób:

Wykres 1. Klasyfikacja strategii komunikacyjnych

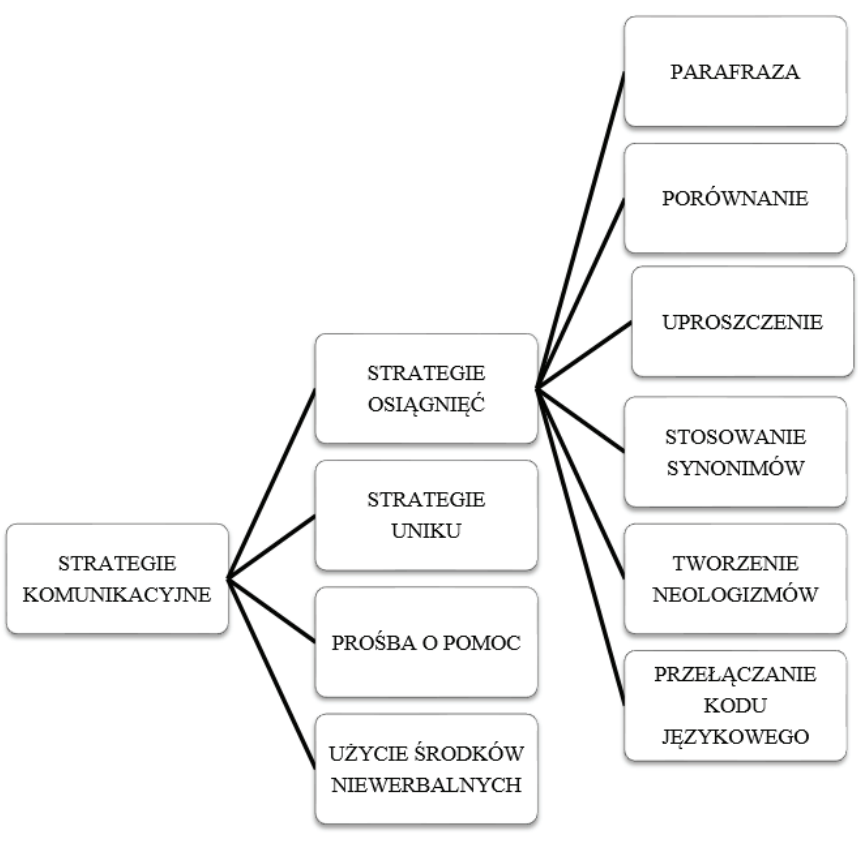

Źródło: opracowanie własne

Klasyfikację, którą zastosowałam przy omawianiu działań strategicznych cudzoziemców, traktuję jedynie jako punkt wyjścia, ponieważ kategorie pozostają otwarte. Kreatywność uczących się języka polskiego jest duża, stąd mój wniosek, że przy analizowaniu strategii komunikacyjnych należy być gotowym na ewentualne zmiany czy tworzenie nowych kategorii. 


\section{PODSUMOWANIE}

W artykule przedstawiłam przykładowe działania cudzoziemców uczących się języka polskiego, które stosowali, aby osiągnąć założone cele komunikacyjne. W przypadku strategii osiągnięć, wyróżniłam dodatkowo parafrazę, porównywanie, uproszczenie, stosowanie synonimów, tworzenie neologizmów oraz przełączanie kodu językowego. Wśród strategii stosowanych przez uczących się pojawiły się też takie, które zostały sklasyfikowane jako prośba o pomoc lub użycie środków niewerbalnych. Omówiłam również przykłady negocjowania znaczeń, na które składają się różne typy strategii. Zwróciłam również uwagę na coraz częstsze wykorzystywanie nowoczesnych technologii, które okazują się pomocnym narzędziem przy stosowaniu strategii komunikacyjnych.

Przedstawione zachowania uczących się języka polskiego w przypadku napotkania trudności podczas komunikacji pokazują, że wielokrotnie osiągali oni założony cel komunikacyjny, nie zaprzestawali rozmowy, wręcz przeciwnie, znajdowali różne sposoby, by ją kontynuować. Szeroki repertuar strategii komunikacyjnych okazywał się przydatny podczas negocjowania znaczeń, gdy stosując różne strategie, uczący się mogli sprawnie i efektywnie prowadzić rozmowę. Należałoby się więc zastanowić, czy i w jakim stopniu nauczyciel powinien trenować konkretne strategie, by pomóc uczącym się usprawnić komunikację mimo braków językowych ${ }^{9}$. Sądzę, że zagadnienie to jest warte uwagi badaczy zajmujących się strategiami komunikacyjnymi.

\section{BIBLIOGRAFIA}

Bialystok E., 1990, Communication Startegies: A Psychological Analysis of Second Language Use, Oxford.

Canale M., Swain M., 1980, Theoretical Bases of Communicative Approaches to Second Language Teaching and Testing, „Applied Linguistics”, nr 1, s. 1-47.

Dorneyi Z., 1995, On the Teachability of Communication Strategies, „TESOL Quartely”, nr 29, s. $55-84$.

Dornyei Z., Scott M. L., 1997, Review Article: Communication strategies in a second language: Definitions and taxonomies, „Language Learning”, t. 47, nr 1, s. 173-210.

Europejski system opisu kształcenia językowego: uczenie się, nauczanie, ocenianie, 2003, thum. W. Martyniuk, Warszawa.

Faerch C., Kasper G., 1983, Plans and strategies in interlanguage communication, w: Fearch C., Kasper G. (red.), Strategies in interlanguage communication, London, s. 20-60.

${ }^{9} \mathrm{O}$ rozwijaniu strategii komunikacyjnych przez nauczyciela piszą Pawlak (2006), Janowska (2010). 
Janowska I., 2010, Strategie językowe $i$ działania komunikacyjne $w$ podejściu zadaniowym, w: R. Nycz, W. Miodunka, T. Kuntz (red.), Polonistyka bez granic. Tom 2: Glottodydaktyka polonistyczna - wspótczesny język polski - językowy obraz świata, Kraków, s. 81-92.

Kellerman E., 1991, Compensatory Strategies in Second Language Research: a Critique, a Revision and Some (Non-)Implications for the Classroom, w: R. Phillipson, E. Kellerman, L. Selikner, M. Sharwood Smith, M. Swain (red.), Foreign/Second Language Pedagogy Research: A Commemorative Volume for Claus Faerch, Clevedon, s. 142-161.

Kellerman E., Ammerlaan T., Bongaerts T., Poulisse N., 1990, System and hierarchy in L2 compensatory strategies, w: R. Scarcella, E. Andersen, S. Krashen (red.), Developing communicative competence in a second language, New York, s. 163-178.

Kubacka K., 2014, Komunikacja werbalna lektora na lekcji języka polskiego jako obcego: wprowadzanie nowych treści a strategie negocjacyjne lektora, „Acta Universitatis Lodziensis. Kształcenie Polonistyczne Cudzoziemców”, t. 21, E. Pałuszyńska, B. Grochala, I. Dembowska-Wosik, M. Wojenka-Karasek (red.), s. 85-97.

Pawlak M., 2006. Kompetencja strategiczna i strategie komunikacyjne na lekcjach języka obcego, „Języki Obce w Szkole”, nr 4, s. 35-45.

Piotrowski S., 2016, Strategie komunikacyjne, czyli jak uczacy radza sobie z deficytami leksykalnymi w klasie języka obcego, „Języki Obce w Szkole”, nr 1, s. 26-31.

Poulisse N., 1990, The Use of Compensatory Strategies by Dutch Learners of English, Dordrecht.

Seretny A., Lipińska E., 2005, ABC metodyki nauczania języka polskiego jako obcego, Kraków.

Sękowska E., 2010, Język emigracji polskiej w świecie. Bilans i perspektywy badawcze, Warszawa.

Wojtczak E., 2017, Strategie komunikacyjne stosowane przez cudzoziemców na lekcjach języka polskiego jako obcego na poziomach Al i Al, w: R. Maćkowiak i E. Wojczak (red.), Bogactwo językowe i kulturowe Europy w oczach Polaków i cudzoziemców, Łódź, s. 71-79.

Yule G., Tarone E., 1997, Investigating communication strategies in L2 reference: Pros and cons, w: G. Kasper, E. Kellerman (red.), Communication Strategies: Psycholinguistic and Sociolinguistic Perspectives, New York, s.17-30.

Żurek A., 2018, Strategie komunikacyjne osób dwujęzycznych. Na przykładzie polszczyzny odziedziczonej w Niemczech, Kraków.

Edyta Wojtczak

\title{
COMMUNICATIONS STRATEGIES AS A MEANS TO EFFECTIVE COMMUNICATION DESPITE LANGUAGE DEFICIENCIES
}

Keywords: communication strategies, Polish as a foreign language, spoken language

\begin{abstract}
The author discussed the concept of communication strategies and the two most popular research approaches: interactive and sociolinguistic. She presented strategic activities of students learning Polish as a second language, which appeared during the classes held at the Polish Language Center for Foreigners at the University of Lodz, both during the observation of the lesson and during the classes conducted by the author. These strategies included: achievement strategies (paraphrase, comparison, simplification, use of synonyms, neologisms, and language code switching), help request, non-verbal means, and avoidance strategies. The author also discussed examples of negotiating meanings and the use of modern technologies as a helpful tool in applying communication strategies.
\end{abstract}

